\title{
Danielboek as apokaliptiek ${ }^{1}$
}

M Nel

(Navorsingsassosiaat, Universiteit van Pretoria)

\section{ABSTRACT}

\section{The Daniel book as apocalips}

The tales in the Book of Daniel (Dan 1-6) do not have typical apocalyptic features. The tales form part of a book that also includes visions (Dan 7-12) that exhibit definite apocalyptic features. The question is posed: must the tales be interpreted as apocalyptic literature because the writer in the second century placed it as a prologue to the book with its apocalyptic message of the end of all known kingdoms? To answer the question, it is first necessary to define what apocalyptic literature comprises. This is a difficult question, because each apocalyptic work has unique features. To answer the question on the historic and social origin of apocalypticism difficulty is also encountered because the modern researcher does not have precise historical information relating to the phenomenon of apocalypticism. This article concludes that each apocalyptic work should be investigated on its own right, and that the tales in the Book of Daniel should be interpreted with the writer's apocalyptic aims in mind.

\section{INLEIDING}

Die verhale in die Daniëlboek (Dan 1-6) vertoon nie apokaliptiese eienskappe nie, met die uitsondering van Daniël 2, wat oor Nebukadnesar se droom handel'. Die verhale vorm egter deel van die groter

${ }^{1}$ Dié artikel is gebaseer op navorsing wat ek onder leiding van prof D J Human in 1999 en 2000 gedoen het, en in 'n proefskrif getiteld "'n Teologies-hermeneutiese ondersoek na Daniël 1 en 2" vervat het, ter vervulling van die vereistes van die $\mathrm{Ph}$ D-graad by die Universiteit van Pretoria.

${ }^{2}$ Baldwin (1978:46) sê dat Jeffery en Humphries die verhale oor Nebukadnesar, Belsasar en Darius (Dan 1, 3-6) sien as hofverhale, Heaton dit sien as populêre romanses, en Von Rad dit sien as wysheidstyldramas in die tradisie van die Josefverhale in Genesis. Daar is min daarin wat aan sogenaamde apokaliptiese eienskappe herinner. Baldwin (1978:51) meen dit is nie nodig om die verhale aan ' $n$ ander genre toe te skryf nie. Dit is te nou ingebed in die hele boek. Apokaliptiek is in staat om talle verskillende literêre vorme aan te neem en dit in ' $n$ geheel te verbind. Dit is een rede hoekom dit so moeilik is om 'n omvattende definisie van apokaliptiek te gee. LaCocque (1988:183) maak die opmerking dat as ons net Daniël B (Dan 7-12) tot ons beskikking gehad het, dit maar valerig sou vertoon het. Die verhale demonstreer 
geheel van die boek, wat dit onmoontlik maak om die verhale los van die visioene te lees ${ }^{3}$. Dit beteken dat die apokaliptiese milieu wat in Daniël 7-12 voorkom, noodwendig bydra tot die agtergrond waarteen die leser die res van die verhale lees. Hieruit vloei die vraag wat in die verklaring van die Daniëlverhale essensieel is, naamlik of die Daniëlverhale (Dan 1-6) ook apokalipties verklaar moet word op grond daarvan dat dit in ' $n$ boek met duidelike apokaliptiese trekke opgeneem is.

\section{DIE DANIËLBOEK AS APOKALIPTIESE LITERATUUR}

\subsection{Inleiding}

Le Roux (1988:2) maak die opmerking dat die Daniëlboek die enigste in die Ou Testament is wat "eskatologies" genoem kan word. Met die term "eskatologie" bedoel hy letterlik die kennis van die einde van die huidige periode, die teenwoordige tyd en die kort rukkie wat die einde voorafgaan. Israel verwag die openbaring van JHWH in die toekoms. Die Een wat Hom sal openbaar om sy volk te red, het Hom reeds in die verlede geopenbaar. Eskatologie en geskiedenis is onafskeidbaar. Die eskatologie is nie ' $n$ toevallige addendum nie, maar ' $n$ essensiële en integrerende deel van die geloof in God wat in die Ou Testament beskryf word.

Die profete het ook vir die openbaring van God gewag, in dieselfde terme as waar Hy Hom aan sy verdrukte volk in Egipte deur Moses geopenbaar het. Na Deuterojesaja, Haggai en Sagaria besef die Jode dat God hulle nie in die geskiedenis red nie, en heil word na die toekoms verplaas. Hieruit ontstaan ' $n$ nuwe vorm van eskatologie (Le Roux 1988:4).

op ' $n$ lewendige en hoogs interessante wyse die teologiese waarheid wat ook in die visioene weergegee word, maar daar op ' $n$ enigmatiese wyse. Montgomery (1927: 89) meen hoofstuk 2 is nie apokaliptiek nie. Dit is niks meer as die storie van ' $n$ koning se droom wat sy angs oor sy onmiddellike toekoms en sy opvolgers reflekteer nie. Gammie (1976:191) sien ook slegs Daniël 7-12 as apokaliptiek. Hy meen Daniël 2 is nie ' $n$ apokalips nie, omdat dit oor God se alwetendheid en almag handel. Die verhouding met die koning word ook as positief beskryf. So ' $n$ siening ignoreer egter die verwysing na ' $n$ vyfde ryk, wat 'n einde aan aardse ryke maak.

3 ' $n$ Probleem kan maklik ontstaan as ' $n$ teks in terme van ' $n$ sekere verwagting gelees word, sonder dat die teks op sigself ernstig geneem word. Balzer (1991:408) verwys hierna: "In exegetical praxis, eschatology is normally used as a key ... this hermeneutical approach can have an intrinsic danger of becoming an a priori principle in biblical exegesis, the interpreter's conditio sine qua non, instead of the reverse. Therefore, exegesis usually radically adapts or eliminates contextual elements that do not fit into the general pattern ..."Vergelyk ook die opmerking in Rendtorff (1985:276) dat die visioene in Daniël 7-12 die droom van Daniël 2 op datum wil bring in die lig van die veranderde omstandighede tydens die Makkabese opstand. Dit plaas druk op die verklaring van Daniël 2, sodat dit apokalipties gelees moet word. 
Le Roux (1988:5) pas Vriezen se werk van 1953 aan om vier periodes in die eskatologie van Israel te onderskei:

- 'n pre-eskatologiese periode, voor die klassieke profete optree, as die toekoms in die lig van die verlede beskryf word. Amos praat so van die Dag van JHWH;

- ' $n$ ontwakende eskatologie, met Jesaja en Jeremia, wat praat van ' $n$ nuwe volk en ' $n$ nuwe koninkryk wat die hele wêreld omvat;

- ' $n$ aktualiserende eskatologie, met Deuterojesaja $a^{4}$, wat Israel as die lig vir die nasies sien, en die nasies as vennote in die heil;

- 'n apokaliptiese eskatologiese periode. Dit bestaan uit ' $n$ dualistiese eskatologie waar God en die wêreld geskei word, in die plek van die eenheid wat voorheen tussen plek en tyd (hierdie wêreld) en aksie (God wat werk) bestaan het. Nou word 'n nuwe koninkryk verwag, wat verby tyd na die ewigheid sal strek. God is ook nie meer die enigste handelende figuur nie, maar ander figure word voorgestel. Die Daniëlverhale val in dié periode.

Dit beteken dat die nuwe in terme van die oue verwag word: Hosea praat van ' $n$ nuwe ingang in die land, Jesaja van ' $n$ nuwe Dawid wat in Sion sal regeer en Jeremia van ' $n$ nuwe verbond. Deuterojesaja praat van ' $n$ nuwe eksodus en Daniël van ' $n$ nuwe koninkryk (Dan 2 se vyfde ryk). Die heilsgeskiedenis bly die norm vir die verwagting oor die laaste dae.

Die teleurstelling as die profesieë oor God se openbaring nie realiseer nie, lei tot ' $n$ herinterpretasie van die profesieë. Le Roux (1988:19) haal Robert Carrol aan wat praat van "cognitive dissonance" om die nievervulling van profetiese voorspellings te illustreer wat tot herinterpretasie lei. Kognitiewe dissonansie kom voor as kognisie en gebeure nie saamval nie. Dit word opgelos deur die sosiale ondersteuning van ' $n$ groep mense wat op dieselfde wyse dink, en herinterpretasie wat vir die gaping tussen eskatologie en realisering voorsiening maak (Le Roux $1988: 22)^{\text {s. So }}$ word die val van Jerusalem en die herbou van die tempel geherinterpreteer ${ }^{6}$.

\footnotetext{
${ }^{4}$ Jesaja word aan Amos, Hosea en Miga gekoppel omdat hulle in sy tradisie optree, terwyl Haggai, Sagaria en Tritojesaja die tradisie van Deuterojesaja voortsit.

${ }^{5}$ Premillenialistiese dispensasionalisme hou die apokaliptiek van die Bybel oop deur die laaste toneel van die eindtyd-scenario slegs vorentoe te skuif. So word dit na ons eie tyd verskuif: as die planete in 1987 in lyn kom, of die millennium draai, ensovoorts. Die teologiese waarheid van die Bybelse apokaliptici kan egter op ' $n$ meer verantwoordelike wyse, volgens Towner (1987:281), erken en lewend gehou word. Dit word gesien as paradigmas van die ervaring van God se reddende mag oor die dood, die bose en verval. Dit is slegs modelle, tipes en paradigmas wat elke ervaring betekenisvol maak en die houding teenoor die toekoms bepaal. Deur die apokalipse
} 
Alhoewel eskatologie uit toekomstige hoop groei, is daar ' $n$ groot verskil. Toekomstige hoop hou die oog op die toekomstige openbaring van God in die toekoms. Eskatologiese hoop groei tot waar dit die daad word, om op die grenslyn tussen twee duidelik onderskeie eras te staan. Hier kyk eskatologiese hoop in die afgrond waar die beskawings vernietig gaan word. Die vernietiging is die voorwaarde vir die aanbreek van God se nuwe?

Dat die einde vir Daniël nie die einde is wat talle Christene voorsien, in terme van hul verwagting van ' $n$ nuwe hemel en 'n nuwe aarde nie, is duidelik uit die taal wat in die boek gebruik word. Die tweede hoofstuk praat van die vernietiging van al die koninkryke, en die opkoms van ' $n$ nuwe ryk wat die hele aarde sal vul. Die einde is derhalwe slegs 'n krisis wat tot "n nuwe periode lei. Dié definisie van "qes" word ook by 1 Henog 1 tot 36 asook 1 Henog 91 tot aan die einde van die boek gevind, met die uitsluiting van die "Apokalips van die Weke" wat anders daarna kyk. Dit beskryf die einde in terme van die oorgang na ' $n$ volgende periode (Collins 1974:26-27) ${ }^{8}$.

Ek meen dat, net soos dit beslissend in die interpretasie van die Daniëlverhale is om te onthou dat die verhale in die tweede eeuse krisis rondom Antiochus IV se helleniseringsbeleid ontstaan het met ' $n$ bemoe-

as tydtafels te sien, misken die leser dat die Woord in menslike vorm na ons toe kom.

6 "The apocalyptists came to the shocking conclusion that since the fall of Jerusalem in 587 B.C. God was relatively absent in history. This rude awakening did not come forth from a specific theory but was based on their experience of history. The apocalyptists experienced more and more the absence of God from that stage of history in which they themselves lived. God no longer miraculously intervened in the history of His people as in the former days" (Le Roux 1981:42).

${ }^{7}$ Sien egter Collins (1974:37) wat meen dat die wêreldbeeld van apokaliptiek nie om twee eras draai nie, maar om twee verdiepings. Dit gaan nie soseer om nou en dan nie, maar om hier en daar. Sien ook Stahl (1994:18) se voorstel, wat onaanvaarbaar is, dat die periodisering van die geskiedenis nie slegs vanuit die ervaring van veranderinge in wêreldmagte kom nie, maar veral "aus der Beobachtung der Gültigkeit astronomischer Gesetzmässigkeiten". "Auch bei der Interpretation der Texte der Danielbibliothek muss immer ein möglicher Zusammenhang $\mathrm{zu}$ astronomischastrologischen Vorstellungen eingerechnet und gegebenfalls reflektiert werden" (Stahl 1994:19).

${ }^{8} \mathrm{n}$ dié sin was die middeleeuse gebruik wat onder andere in die illustrasies voorkom vir die Daniëlboek deur die dames van Magdeburg, gepas: die stryd tussen Daniël en die heidense koning word geskets in terme van pous Innocentius III se oorlog teen die verbanne keiser Otto IV, met die pouslike magte as die oorwinnaars (Stahl 1994:12). Eichrodt (1961:470) praat van die apokaliptiese idee van die onomkeerbare finaliteit en totaliteit van die komende wêreldkatastrofe. Dit sal gekenmerk word deur ' $n$ totale vernietiging van die hele kosmos deur vloed en vuur, en ' $n$ finale oordeel wat verbind is aan die opstanding. Die Daniëlboek leen hom nie tot so ' $n$ begrip van die einde nie. 
digend doelstelling, dit belangrik is om in gedagte te hou dat die skrywer se doelstelling met die visioene is om die einde van alle menslike konink-ryke aan te kondig, en die vestiging van 'n Joodse koninkryk wat onbepaald lank heers. Die skrywer voorsien ' $n$ einde wat die begin van ' $n$ nuwe era is. Die verhale behoort in terme hiervan verstaan te word. Meer moet egter oor die verskynsel van apokaliptiek en apokaliptiese literatuur gesê te word voor die navorser die Daniëlboek as apokalipties van aard kan interpreteer.

Hilton (1995:99) onthou hoe H H Rowley in 1942 gesê het dat in krisistye daar altyd ' $n$ ontwaking van apokaliptiek is'. In dieselfde verband het Käsemann reeds beweer dat apokaliptiek die moeder van alle Christelike teologie is ${ }^{10}$. Koch (1972:14) meen dat Käsemann se opmerking die begin aandui van moderne belangstelling in die onderwerp van apokaliptiek. Koch se opmerking het as ' $n$ groot skok vir Duitse teoloë gekom wat op Bultmann se ontkenning van enige verbintenis tussen ' $n$ Christelike eskatologie en ' $n$ Joodse apokaliptiek gestaan het. In dieselfde tyd publiseer Pannenberg sy lesing waarin hy as deel van sy gekiedenisfilosofie apokaliptiek as ' $n$ essensiële skakel in die ontwikkeling van egte historiese begrip beskryf.

Rowley se opmerkings het in 1944 reeds die Engelssprekende wêreld van die belang van apokaliptiek bewus gemaak. Frost (1952) en Plöger (1959; sy werk is in 1968 in Engels vertaal) skryf in Rowley se tradisie. Ook Von Rad (1965:301-315) se bekende standpunt dat apokaliptiek uit wysheid groei, vestig aandag op die verskynsel van apokaliptiese literatuur.

Käsemann en Pannenberg lei nie ' $n$ beweging in nie. Hulle is eerder deel daarvan (Oswalt 1999:370). Moderne belangstelling in apokaliptiek het eerder met die aard van gebeure in die moderne tyd te doen, sê Russell (1971:5). Die moderne mens sien soms nie kans om met die lewe

\footnotetext{
${ }^{9}$ Dit sien ons weer in die einde-van-die-wêreldscenarios wat voorkom by die kerke en bewegings wat ontstaan het rondom onder andere (om slegs die bekendstes te noem) die Subgenius, Hong-Ming Chen, Branch Davidians, Vladimia Sobolyov, The order of the solar temple, The House of Yahweh, Arnie Stanton, Terence McKenna, Greenpeace en J Richard Gott III (Cox 1998:22-23). Johnson (1988:55) sien in Karl Marx een van die grootste (en mees misleide) eskatologiese skrywers van ons dag, wat die einde van ' $n$ wêreldorde voorsien het en alles in diens daarvan gestel het. Ook Tolstoy het voortdurend gekyk na ' $n$ reuse morele ommekeer, wat die wêreld op sy kop sal laat staan en ' $n$ hemelse koninkryk vestig. Sy eie utopiese verkondiging was gerig om die millennialistiese gebeure te help realiseer (Johnson 1988:129).

${ }^{10}$ Towner (1987:287) meld die interessante feit dat slegs Marxisme en Islam van alle godsdienste en denkrigtings ' $n$ eskatologie aanbied. By albei is dit ' $n$ hoogs verkorte eskatologie omdat dit onderskeidelik beperk word tot die effektiewe uitroeiing van die ongelowiges en kapitaliste.
} 
aan te gaan asof alles normaal is nie. Gebeure is te abnormaal daarvoor ${ }^{11}$. Dié mense formuleer ' $n$ nuwe geskiedenisfilosofie wat die gebeure inkorporeer en transendeer.

Buiten vir Russell se sosiologiese verduideliking vir moderne belangstelling in apokaliptiek, bied Collins (1984b:1, 12-13) ' $n$ intellektuele rede. Wellhausen se siening van Israel se geskiedenis het vir die eerste helfte van die twintigste eeu teologiese denke oorheers. Sy siening ontneem apokaliptiek enige waarde. Hy beskou dit as ' $n$ ontkenning van die "ware" Ou Testamentiese geloof. Collins meen die verskuiwing in teologies-historiese denke het dit moontlik gemaak dat apokaliptiek nuut geëvalueer kan word.

\subsection{Wat is apokaliptiek?}

Davies (1985:66) se waarskuwing is gepas: “'Apocalyptic' and 'apocalypticism' are notoriously slippery words". Die twee vrae wat navorsers besig hou, is: Wat is apokaliptiek? En waar kom dit vandaan? Dié vrae het met definisie en oorsprong te doen.

Die historiese inligting vir die periode waarin Joodse apokaliptiek ontstaan $(300 \mathrm{vC}-200 \mathrm{nC})$, is so skraps dat albei vrae probleme veroorsaak. Dit is nie bekend wie die literatuur geskep of gelees het, of hoe wyd die invloed daarvan op die Joodse samelewing was nie. Daarom sukkel die moderne navorser om selfs te bepaal wat die presiese kenmerke van apokaliptiese literatuur is. Wanneer al die lyste van kenmerke met mekaar vergelyk word, voldoen nie een van die apokaliptiese tekste aan al die kenmerke nie.

\subsubsection{Kenmerke van apokaliptiek}

'n Opsomming van enkele lyste skryf aan apokaliptiek verskeie kenmerke toe, wat soos volg saamgevat kan word:

- dit is openbarings deur buitewêreldse bemiddelaars, aan ' $n$ menslike ontvanger, wat handel oor redding en verlossing uit die ellendes van die huidige wêreld;

- redding kom vanuit die bonatuurlike ruimte;

- dit bevat ' $n$ eskatologiese dualisme, met ' $n$ duidelike differensiasie tussen twee aeone - die huidige teenoor die ewige, die tyd van die bose teenoor triomfantelike verlossing, die aardse en die dood teenoor die hemelse, onregverdiges en die bose teenoor die uitverkorenes en regverdiges;

\footnotetext{
${ }^{11} \mathrm{Om}$ slegs een voorbeeld te noem, Krog (21 Junie 2000:1-6) vertel van die moord van een miljoen mense binne honderd dae na die Rwandese president in April 1994 dood is. Hoe reageer mense ná hulle die doodskampe van Hitler of Stalin oorleef het?
} 
- dit voorsien dat alles op pad na die einde vooraf bepaal of gepredetermineerd is;

- dit is pseudoniem, wat Hanson (1979:9) toeskryf aan die skrywer se soeke na kredietwaardigheid by sy lesers/hoorders;

- dit word geheim gehou, omdat dit nie eens deur die skrywer ten volle verstaan word nie; Davies (1985:120), en Von Rad (1965:308), wat vaagweg daarna verwys) suggereer dat dit die begin van Gnostiek kan wees. Die rede wat Davies aanvoer is dat apokaliptiek groot waarde aan esoteriese kennis heg. In Gnostiek is die kuns om voorspellings te dekodeer, baie belangrik;

- dit word gekenmerk deur eskatologiese ongeduld;

- daar kom gereeld noukeurige berekeninge van toekomstige gebeurtenisse voor;

- die visioene word gekenmerk deur 'n wye strekking en fantasie;

- getalle-simboliek speel 'n groot rol;

- apokaliptiek ken aan engele ' $n$ prominente rol as boodskappers van God toe, en hul taak is om in belang van die gelowiges op te tree;

- ' $n$ verwagting van lewe na die dood word verwoord (Von Rad 1965:301-302; Vorster 1986:158-9; LaCocque 1988:88 en Verhoef 1993:83).

Hanson (1979:6) waarsku dat so 'n lys se waarde hoogs beperk is omdat verskillende werke unieke eienskappe vertoon. Dit veroorsaak dat die bronne van apokaliptiek dikwels verkeerd verstaan word. Die navorser kyk mis dat die historiese en sosiale matriks van apokalips nie deur die lyste van eienskappe verreken word nie. Dit impliseer dat die essensiële aard van apokaliptiek nie verklaar word nie ${ }^{12}$.

Om na die Daniëlboek as apokaliptiek of apokaliptiese literatuur te verwys sonder dat verdere kwalifikasies daaraan gegee word, is om die obskure te verduidelik aan die hand van die meer obskure. Dit veroorsaak meer probleme as wat dit oplos. Apokaliptiek is 'n krisisverskynsel, waar die waardes en strukture van die samelewing vir ' $n$ minderheidsgroep sinloos word en vervang word met ' $n$ nuwe betekenisstelsel. Op dié manier word die minderheidsgroep nog meer vervreem, 'n marginale groep of substruktuur wat in konflik met die meerderheidsgroep leef. Vir dié groep lê die sin van die lewe in die aanbreek van 'n nuwe wêreld, as

${ }^{12}$ Hanson (1979:6) vra wat die nut van 'n lys soos dié van D S Russell is, wat die eienskappe van apokaliptiek noem: transendentalisme, mitologie, kosmologiese oriëntasie, pessimistiese wêreldbeeld, dualisme, verdeling van tyd in eras, numerologie, pseudo-ekstase, kunsmatige eise van inspirasie, pseudonimiteit, esoterisme, eenheid van geskiedenis, konsep van kosmiese geskiedenis, spekulasie oor bronne van bose in wêreld, konflik tussen lig en duisternis, goed en kwaad, God en Satan, die seun van die mens, lewe na die dood, individualisme. Hoe kan so ' $\mathrm{n}$ beskrywing bydra dat apokaliptiek beter verstaan word? 
God afreken met die meerderheid ${ }^{13}$. "An apocalypse is ... designed to be the revelation of the divine revelation as this takes place in the individual acts of a coherent historical pattern" (Koch 1972:33). Of in die woorde van Hanson (1995:10): “...apocalyptic eschatology is the mode assumed by the prophetic tradition once it had been transferred to a new and radically altered setting in the post-exilic community".

Barker (1977-1978:325) meld dat moderne navorsers dikwels die Daniëlboek as uitgangspunt gebruik om oor apokaliptiek te dink ${ }^{14}$. Tog bevat Daniël nie al die eienskappe wat in lyste voorkom nie. Russell (1992:104) meen die probleem is dat enige lys ' $n$ hoogs komplekse verskynsel probeer vereenvoudig.

\subsubsection{Onderskeidinge}

' $n$ Nuttige onderskeid het uit die diskussie gegroei, tussen literêre genre (apokalips), ' $n$ sosiale ideologie (apokaliptisisme) en literêre idees en motiewe (apokaliptiese eskatologie). Apokalips is ' $\mathrm{n}$ teks, terwyl apokaliptiese perspektief na ' $\mathrm{n}$ gesigshoek verwys waaruit die werklikheid beleef word. ' $n$ Apokaliptiese beweging is ' $n$ groepering binne die maatskappy, terwyl apokaliptiek na 'n verskynsel of ideologie verwys (sien Vorster 1986:158). Die onderskeid los egter nie alle probleme op nie. So meld Martínes (1987:230) dat die beperking van "apokaliptiek" tot ' $n$ literêre genre te reduksionisties is om reg aan die onderwerp te laat geskied.

In plaas van ' $n$ definisie is dit beter om ' $n$ beskrywing van die verskynsel te gee, en om dit te beperk tot 'n enkele dokument. Eers hierna kan dokumente met mekaar vergelyk word, sodat die versoeking weerstaan word om ' $n$ teks met a priori persepsies te lees's.

\footnotetext{
${ }^{13}$ Larue (1968:3) stem saam: "The fundamental theological problem confronting the apocalypticist is theodicy. The struggle between good and evil experienced in human life is a microcosmic manifestation of a macrocosmic phenomenon". Larue (1968:3) noem ook dat Antiochus IV se vervolging van die Jode die katalisator word vir apokaliptiese denkpatrone. Die denke se wortels lê in Israel se sakrale geskiedenis. Die Antiochus-vervolgings lei tot "a failure of nerve, a despair of man's ability to effect the kingdom of God through his own efforts and a conviction that the situation could only get worse until God himself broke in to terminate the present evil age and inaugurate the ideal".

44 "Das Buch Daniel ist das einzige apokalyptische Buch des AT. In der Gattung der atl Apokalypen gehören auch die in Jes 24-27 vorliegende Jesaja-Apokalypse und die sog. Kleine Apokalypse in Jes 33" (Zenger 1998:458).

${ }^{15}$ Dit is Porteous (1979:16) se raad: "Perhaps the wisest course is to take the Book of Daniel as a distinctive piece of literature with a clearly defined witness of its own ... it borrows from and is coloured by the earlier prophetic literature, the Wisdom literature and the Psalms and has its successors in the apocalypses...."
} 


\subsubsection{Genre}

Nie almal stem saam dat daar van 'n genre, apokaliptiek, gepraat kan word nie ${ }^{16}$. Fiorenza (1983:295) wys daarop dat Käsemann in die 1960s van apokaliptiek as die moeder van die vroeë Christelike teologie gepraat het, terwyl Kurt Koch in die 1970s sy boek se titel ontleen het aan sy stelling dat geleerdes "ratlos vor der Apokalyptik" te staan gekom het ${ }^{17}$.

Die regte vraag, waarop ' $\mathrm{n}$ antwoord waarskynlik nie moontlik is nie, is: het die oorspronklike lesers 'n onderskeie genre bemerk toe hulle dié boek gelees het? Indien nie, sou die oorspronklike lesers dit gelees het teen die konteks van literatuur wat aan hulle bekend is. Dit is die konteks van profesieë en drome van die Ou Testament, politieke pseudoprofesieë en droomuitlegte wat bekend is uit tweede eeuse Babel, asook die verhale oor Daniël in die eerste deel van die boek. Feit is: die benaming apokaliptiek en apokaliptiese literatuur het "notoriously slippery words" (Davies 1985:66) geword. Porteous (1979:16) is dalk in die regte rigting op pad as hy die raad gee dat Daniël eerder as ' $n$ unieke en onderskeie stuk literatuur beskou moet word met ' $n$ duidelik gedefinieerde getuienis van sy eie. Die visioene van Daniël is sui generis (Davies 1985:68). Dit doen nie afbreuk aan die feit dat die boek wel van die Wysheidsliteratuur en die profetiese boeke en die Psalmboek leen nie, of dat daar genoeg navolgers was wat dit moontlik maak om van ' $n$ apokaliptiese beweging te praat nie. Porteous (1979:182) maak ook die stelling dat dit wyser is om die boek te interpreteer in die lig van sy voorgangers, eerder as sy navolgers. Dit noodsaak ' $n$ verbintenis tussen die interpretasie van die profeteboeke en Daniël. Die Daniëlboek is nie blote Wysheidsliteratuur nie. Wysheid het met algemene probleme van menslike bestaan te make, terwyl apokaliptiek hom met besondere historiese krisisse bemoei. "In Daniel something of old prophetic inspiration is present again confronting the challenge of a new day" (Porteous 1979:17).

Collins (1984a:4) poog om die makrogenre van apokalips te omskryf. Die span navorsers van Semeia doen dit soos volg:

\footnotetext{
${ }^{16}$ Daar bestaan 'n verwarring van terme: die Duitse "Gattung" is " $n$ kleiner literêre eenheid, maar word ook "Form" genoem. Die Engelse term "genre" verwys na heel werke soos die evangelies, "n versameling orakels of epiese werke, terwyl "form" gebruik word om kleiner tekseenhede te onderskei.

${ }^{57}$ Koch (volgens Baldwin 1978:16) vind die sosiologiese rede vir die nuwe belangstelling in die vyftiger- en sestigerjare in apokaliptiek, na meer as ' $n$ eeu se verwaarlosing van die onderwerp, in die ontnugtering wat twee Wêreldoorloë veroorsaak het. Martin Luther se aanvanklike opinie oor die apokalipse kom treffend na vore in sy beroemde uitspraak: "Gooi die drome in die Elbe" (De Villiers 1987:16). Lutherse kringe bejeën tot vandag toe oor die algemeen apokaliptiese navorsing met argwaan en suspisie.
} 
- Skryfwyse - narratief ${ }^{18}$;

- Tekstipe - openbaringsgeskrif ${ }^{9}$;

- Genre-apokalips;

- Subgenre - apokalips met ' $n$ anderwêreldse reis.

Dit definieer apokalips as ' $\mathrm{n}$ genre "of revelatory literature with a narrative framework, in which a revelation is mediated by an otherworldly being to a human recipient, disclosing a transcendent reality which is both temporal, insofar as it envisages eschatological salvation, and spatial insofar as it involves another, supernatural world".

Die twee hooftipes is ' $n$ apokalips met en ' $n$ apokalips sonder ' $n$ anderwêreldse reis. 'n Kenmerk van ' $n$ apokalips sonder ' $n$ anderwêreldse reis, soos die Daniëlboek, is dat dit altyd ' $n$ oorsig oor die geskiedenis in een of ander vorm bevat, in die vorm van ' $n$ ex eventu-profesie van geskiedenis. Vir dié rede kan dit gerieflik geëtiketteer word as ' $n$ historiese apokalips. Verdere kenmerke van albei subgenres is dat die ontvanger van die openbaring ' $n$ waardige figuur uit die ou tyd is, wat dui op die pseudonimiteit daarvan. Die narratief bevat gewoonlik ' $n$ beskrywing van een of ander soort van hoe die openbaring ontvang is ${ }^{20}$.

Die voordeel van SBL se definisie is dat dit breed genoeg is om alle dokumente wat as apokalipties beskryf is, in te sluit. Mettertyd mag dit nodig word om enkele subgenres verder te beskryf. So maak Collins

\footnotetext{
${ }^{18}$ Sien De Villiers (1983:47) se kritiek teen die SBL-groep se genredefinisie: dat dit nooit die element, die narratiewe raamwerk, definieer of behoorlik bespreek nie. Dit beteken dat die verhouding tussen ' $n$ apokalips en die genre narratief nooit uitgeklaar word nie. Hy is van opinie dat daar beperkte wyses is waarop die funksies van kommunikasie in taal kan plaasvind: vertelling, eksposisie, argument, beskrywing. Deur dit in ' $n$ lys weer te gee, is volgens sy opinie die hoofmoontlikheid. Apokaliptiese tekste vorm nie ' $n$ aparte genre nie. Dit bevat wel ' $n$ kode, die tekenstelsel van daardie kode en die perspektief as tipiese kenmerke (dit is wat SBL in hul paradigma gelys het). Die apokaliptiese kenmerke is nie die kenmerke van ' $n$ genre nie. Apokalipse kan voorkom in enige van die vyf genres wat hy vermeld as die wyses waarop die funksies van kommunikasie van taal kan voorkom. Openbaring en Henog is byvoorbeeld argumentatief. Apokaliptiese tekste kan ook tot meer as een genre behoort. Hy onderskei so tussen genre en modus waarin die teks geskryf is. Die modus bestaan uit ' $n$ historiese invariant soos narratiewe, epiese, dramatiese of satiriese geskrif. "Apocalypses do not contain narrative parts. They are essentially narrative in character" (De Villiers 1983:49). SBL dui transendensie aan as die sleutelwoord in hul definisie.

${ }^{19}$ Wills (1990:4) gebruik die Aarne-Thompson-indeks van verhaaltipes, en meen Daniël 2 is ' $n$ paradigma van die hoftoneel, Verhaaltipe 922, wat ook in Genesis 41 en die Agikarverhaal voorkom. Sy opmerking dat "genre classification lies in the eye of the beholder" (Wills 1990:193) is ook gepas - daar is byna soveel klassifikasies as navorsers.

${ }^{20}$ Vir ' $\mathrm{n}$ volledige beskrywing van tipes, vergelyk Collins (1979:13-15).
} 
(1984b:6) reeds ' $n$ onderskeid tussen historiese apokalipse en anderwêreldse reise.

Navorsers het twee besware teen dié definisie ingebring. Rowland (1982:11) noem dat die verwagting van ' $n$ nuwe era van heil nie eksklusief in apokalipse gevind word nie. Die verwagting is ' $n$ kenmerk van ' $n$ groot deel van Judaïsme gedurende laat pre-Christelike tye. Hieruit kom hy tot die gevolgtrekking dat dit nie moontlik is om ' $n$ apokaliptiese eskatologie te onderskei nie. Dié eienskap hoort volgens sy mening nie in die definisie van die genre apokalips nie. As die navorser toegee dat eskatologiese belange nie uniek aan apokalips is nie, beteken dit nog nie dat dit nie as een van die genre se onderskeidende kenmerke genoem kan word nie. Dit word immers nie as uniek of eksklusief beskryf, en ook nie as die hoofkenmerk van die genre nie.

Hellholm (1986:26-27) meld nog ' $n$ beswaar. Die definisie bevat geen verwysing na die funksie van die genre nie. Op grond hiervan stel hy ' $n$ byvoeging tot die definisie voor: "intended for a group in crisis with the purpose of exhortation and/or consolation by means of divine authority" (Hellholm 1986:27). Die probleem is dat geen konkrete gegewens bestaan wat dié afleiding onderskryf nie. ' $n$ Meerderheid navorsers aanvaar dit wel. Grabbe (1989:27-47) verteenwoordig ' $n$ ander standpunt. Hy meen dat apokaliptiese geskrifte nie die produk van gemarginaliseerde groepe in krisis was nie, maar eerder van visioenêre groepe wat soos moderne milleniaristiese bewegings funksioneer.

\section{SINTESE}

Die vraag wat beantwoord word, is of die Daniëlverhale apokalipties verklaar moet word op grond daarvan dat dit in ' $n$ boek met duidelike apokaliptiese trekke opgeneem is. Apokaliptiek groei uit kognitiewe dissonansie met die nie-vervulling van profetiese voorspellings. Die oplossing hiervoor lê in die sosiale ondersteuning van 'n groep mense wat op dieselfde wyse dink, om die gaping tussen eskatologie en realisering te herinterpreteer.

Die einde wat die Daniëlvisioene (wat Dan 2 se droom insluit) voorsien, lyk anders as die einde wat talle Christene voorsien. Daniël 2 verwys na die vernietiging van alle koninkryke, en die opkoms van ' $n$ nuwe ryk wat die aarde vul en vir ' $n$ onbepaalde tyd heers. Die einde is derhalwe slegs ' $n$ krisis wat tot ' $n$ nuwe era lei. Die einde is ' $n$ oorgang na ' $n$ volgende periode.

Ten spyte van verskeie lyste van eienskappe wat navorsers saamgestel het van apokaliptiese geskrifte, is dit nie moontlik om ' $n$ volledige definisie wat alle verskynsels hiervan omvat, te bied nie. Die verskillende apokaliptiese werke vertoon unieke eienskappe. Die navorser kom na die opinie van Hanson verder deur op die historiese en sosiale matriks van die verskynsel van apokaliptiese literatuur te let. Ook hier is daar 
egter nie konsensus tussen navorsers nie. Collins poog om die makrogenre van apokalips te omskryf. Verskeie besware word daarteen ingebring.

Apokaliptiek het nie 'n dominante voorouer nie. Die oorsprong moet eerder in ' $n$ kompleks van faktore gesoek word. Die navorser kan ' $\mathrm{n}$ beskrywing van die faktore nêrens anders as in die betrokke apokalips self vind nie.

Die gevolgtrekking is dat die Daniëlverhale, as deel van die boek wat deur ' $n$ tweede eeuse skrywer saamgestel word, apokaliptiese doelwitte het. Die navorser behoort dit in gedagte te hou, net soos sy moet kennis neem dat die verhale bemoedigend is vir Jode wat deur Antiochus IV se helleniseringsbeleid tot die Makkabese opstand gedryf word.

\section{Literatuurverwysings}

Baldwin, J G 1978. Daniel. Tyndale Old Testament commentaries. Leicester: InterVarsity Press.

Balzer, H R 1991. Eschatological elements as permanent qualities in the relationship between God and nation in the Minor Prophets. Old Testament Essays 4 (3), 408-414.

Barker, M 1977-1978. Slippery words III. Apocalyptic. Expository Times 89, 325.

Collins, J J 1974. Apocalyptic Eschatology as the Transcendence of Death. Catholic Biblical Quarterly, XXXVI, 1, 21-43.

- , 1979. Introduction: Towards the morphology of a genre. Semeia 14, Society of Biblical Literature, 1-20.

- , 1984a. Daniel with an introduction to apocalyptic literature. The Forms of the Old Testament Literature Volume XX. Grand Rapids: William B Eerdmans.

- , 1984b. The apocalyptic imagination: An introduction to the Jewish matrix of Christianity.

Cox, C 1998. Apocalypse how? Utne Reader, 22-23.

Davies, P R 1985. Daniel. Old Testament Guides. Sheffield: JSOT Press.

De Villiers, P G R 1983. Solving the riddle? Recent trends in apocalyptic research. Ou Testamentiese Werksgemeenskap van Suid-Afrika, 26, 39-58.

- , 1987. Leviatan aan ' $n$ lintjie. Woord en wêreld van die sieners. Pretoria: Serva.

Eichrodt, W 1961. Theology of the Old Testament. Volume 1. Old Testament Library. London: SCM. Translated by J A Baker.

Fiorenza, E S 1983. The phenomenon of early Christian apocalyptic, in Hellholm, D (ed). Apocalypticism in the Mediterranean world and the Near East. Proceedings of the International Colloquium on Apocalypticism Uppsala, August 12-17, 1979. Tübingen: J C B Mohr (Paul Siebeck), 295-316.

Frost, S 1952. Old Testament apocalyptic: Its origins and growth. London: Epworth. Gammie, J G 1976. The classification, stages of growth, and changing intentions in the book of Daniel. Journal of Biblical Literature, 95 (2), 191-204.

Grabbe, L L 1989. The social setting of early Jewish apocalypticism. Journal for the Study of Pseudepigrapha 4, 27-47.

Hanson, P D 1979. The dawn of apocalyptic. The historical and sociological roots of Jewish apocalyptic eschatology. Revised edition. Philadelphia: Fortress.

-, 1995. Isaiah 40-66. Louisville: John Knox. 
Hellholm, D 1986. The problem of apocalyptic genre and the Apocalypse of John. Semeia 36, 1-32.

Hilton, M 1995. Babel reversed - Daniel chapter 5. Journal for the study of the Old Testament 66, 99-112.

Johnson, P 1988. Intellectuals. London: Weidenfeld and Nicholson.

Koch, K 1972. The rediscovery of apocalypse. Studies in biblical theology. Second series, 22. London: SCM.

Krog, A 21 Junie 2000. Remembering the day Rwanda turned against itself. Daily Mail \& Guardian, 1-6. http://www.mag.co.za/mg/news.

LaCocque, A 1988. Daniel and his time. Studies of personalities of the Old Testament. Columbia: University of South Carolina Press.

Larue, G A 1968. Old Testament life and literature. Chapter 29: The period of Jewish independence. www.infidels.org/library/modern/gerald larue, 1-11.

Le Roux, J H 1981. The "last days" in apocalyptic. Neotestamentica 12, Essays on Jewish and Christian apocalyptic, 41-74.

- , 1988. Eschatology and the prophets (A survey of the research). Old Testament Essays 1 (1), 1-26.

Martínez, F G 1987. Encore 1'Apocalyptique. Journal of Scientific Studies 17, 230.

Montgomery, J A 1927. A critical and exegetical commentary on the book of Daniel. The International Critical Commentary. Edinburgh: T \& T Clark.

Oswalt, J N 1999. Recent studies in Old Testament apocalyptic, in Baker, D W \& Arnold, B T (eds.) The face of Old Testament studies: a survey of contemporary approaches. Grand Rapids, Michigan: Baker Books, 369-390.

Plöger, O 1968. Theocracy and eschatology. Translated by S Rudman. Oxford: Basil Blackwell.

Porteous, N 1979. Daniel. Old Testament Library. Second, revised edition. London: $\mathrm{SCM}$.

Rendtorff, R 1985. The Old Testament. An Introduction. Translated by J Bowden. London: SCM.

Rowland, C 1982. The open heaven: A study of apocalyptic in Judaism and early Christianity. New York: Crossroad.

Russell, D S 1971. The method and message of Jewish apocalyptic. London: SCM.

- , 1992. Divine disclosure: An introduction to Jewish apocalyptic. Minneapolis: Fortress.

Stahl, R 1994. Von Weltengagement zu Weltüberwindung. Theologische Positionen im Danielbuch. Contributions to Biblical exegesis \& theology 4. Kampen: Kok Pharos.

Towner, W S 1987. The preacher in the lion's den, in Mays, J L \& Achtemeier, P J. Interpreting the prophets. Philadelphia: Fortress, 273-284.

Verhoef, P A 1993. Profete en profesie. Kaapstad: Lux Verbi.

Von Rad, G 1965. Old Testament Theology. The theology of Israel's prophetic tradition. Volume Two. Translated by DMG Stalker. London: SCM.

Vorster, W S 1986. Tekste met ' $n$ apokaliptiese perspektief, in Deist, F \& Vorster, W (red), Woorde wat ver kom. Die literatuur van die Ou Testament. Deel 1. Kaapstad: Tafelberg, 158-176.

Wills, L M 1990. The Jew in the court of the foreign king. Ancient Jewish court legends. Minneapolis: Fortress Press.

Zenger, E et al 1998. Einleitung in das Alte Testament. Stuttgart: Kohlhammer. 